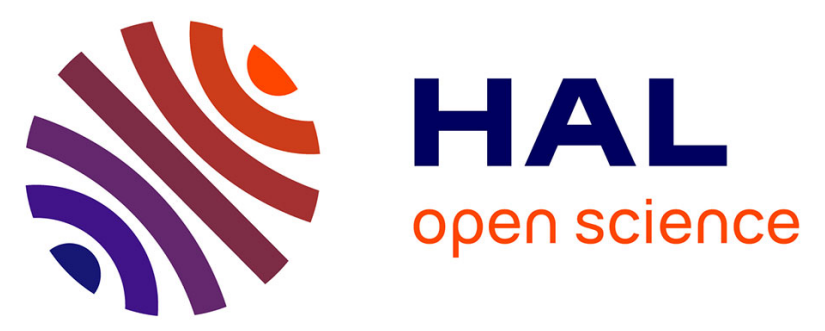

\title{
Voltage-Sensor Probes as efficient tools to screen for new modulators of voltage-gated sodium channels
}

Quentin Coquerel, Anne-Marie Le Ray, Charifat Saïd-Hassane, César Mattei, Nathalie C. Guérineau, Dimitri Bréard, Benjamin Siegler, Pascal Richomme, Christian Legros

\section{To cite this version:}

Quentin Coquerel, Anne-Marie Le Ray, Charifat Saïd-Hassane, César Mattei, Nathalie C. Guérineau, et al.. Voltage-Sensor Probes as efficient tools to screen for new modulators of voltage-gated sodium channels. 22nd Meeting of the French Society of Toxinology (SFET). "Toxins: New Targets and New Functions", Dec 2016, Paris, France. pp.72, 10.1016/j.toxicon.2016.01.004 . hal-03023103

\section{HAL Id: hal-03023103 \\ https://univ-angers.hal.science/hal-03023103}

Submitted on 25 Nov 2020

HAL is a multi-disciplinary open access archive for the deposit and dissemination of scientific research documents, whether they are published or not. The documents may come from teaching and research institutions in France or abroad, or from public or private research centers.
L'archive ouverte pluridisciplinaire HAL, est destinée au dépôt et à la diffusion de documents scientifiques de niveau recherche, publiés ou non, émanant des établissements d'enseignement et de recherche français ou étrangers, des laboratoires publics ou privés. 


\section{Abstracts of oral communications}

\section{LOW-VOLTAGE GATED CALCIUM CHANNELS IN PAIN PATHWAYS: FROM MECHANISMS TO TOXIN IDENTIFICATION}

E. Bourinet. Département de Physiologie, Institut de Génomique Fonctionnelle, CNRS UMR5203, INSERM U661, University of Montpellier, Montpellier, France

Management of pain is an essential aspect for the quality of life; however current therapies are frequently insufficient owing to severe side effects, or limited effectiveness. Therefore, the discovery of new analgesics is crucial. Recent work has shown that specific sets of ion channels are confined to primary afferent neurons where they likely contribute to the detection and transmission of different kinds of nociceptive stimuli. Of interest, we and others demonstrated that the T-type calcium channel Cav3.2 is a key regulator of sensory functions (Bourinet et al., 2014). Nonetheless, Cav3.2 expression pattern within primary afferent neurons and its contribution to modality-specific signaling remain largely obscure. The presentation will focus on recent developments of our work aimed to elucidate this issue using a unique knockin/flox mouse strain where Cav3.2 is replaced by a functional Cav3.2-surface-eclipticGFP fusion. We demonstrate that Cav3.2 is a selective marker of two major low-threshold mechanoreceptors innervating the most abundant skin hair follicles thereby being an essential regulator of their sensory signaling. Strikingly, generation of a C-fiber specific Cav3.2 conditional knockout uncovers that Cav3.2 is essential to build-up debilitating allodynic symptoms of neuropathic pain. Collectively ours findings support a fundamental role for Cav3.2 in touch/pain pathophysiology, validating their critic pharmacological relevance to relieve allodynia and hyperalgesia. In this context, the large potential of venom neurotoxins offers an avenue to discover subtype specific T-type channel blockers with high analgesic potential.

Bourinet, E., Altier, C., Hildebrand, M.E., Trang, T., Salter, M.W., Zamponi, G.W., 2014. Calcium-permeable ion channels in pain signaling. Physiol. Rev. 94, 81-140.

\section{SPIDER TOXINS ACTIVE ON PURINERGIC P2X3 RECEPTOR}

E. Grishin. Laboratory of neuroreceptors and neuroregulators, ShemyakinOvchinnikov Institute of Bioorganic Chemistry, Russian Academy of Sciences, ul/ Miklukho-Maklaya, 16/10, Moscow, 117997 Russia

P2X3 receptors are expressed in mammalian sensory neurons and likely play a substantial role in pain perception. These receptors are ion channels activated by extracellular ATP. The first natural peptide possessing selective inhibitory activity against P2X3 receptors was purotoxin-1 (PT1) isolated from the venom of the Central Asian spider Alopecosa marikovskyi. This peptide contains 35 amino acid residues with four intramolecular disulfide bridges. Another polypeptide named purotoxin-2 (PT2) from the same spider venom consists of 64 amino acid residues also with four disulfide bonds and features C-terminal amidation. Both polypeptides at nanomolar concentrations dramatically depress the activation effect of ATP and promote the desensitization of the P2X3 receptor. It seems likely that when the P2X3 receptors are desensitized, purotoxins bind to them and inhibit receptor activity. PT1 demonstrates potent antinociceptive properties in animal models of inflammatory pain. The preclinical trials of PT1 have been completed.

\section{VOLTAGE-SENSOR PROBES AS EFFICIENT TOOLS TO SCREEN FOR NEW MODULATORS OF VOLTAGE-GATED SODIUM CHANNELS}

Q. Coquerel ${ }^{a}$, A.-M. Le Ray ${ }^{b}$, C. Said Hassane ${ }^{a, b}$, C. Mattei ${ }^{a}$, N.C. Guérineau $^{\mathrm{a}}$, D. Bréard ${ }^{\mathrm{b}}$, B. Siegler ${ }^{\mathrm{b}}$, P. Richomme ${ }^{\mathrm{b}}$, C. Legros $^{\mathrm{a}, *}{ }^{\mathrm{a}}{ }^{\mathrm{a}}$ BNMI, UMR CNRS 6214 - UMR INSERM 1083, Faculté de Médecine - Rue Haute de Reculée, 49045 Angers cedex, France; ${ }^{\text {b } E A ~} 921$ SONAS/SFR QUASAV, UFR des Sciences Pharmaceutiques et d'Ingénierie de la Santé, 16 Bd Daviers, 49100 Angers, France

Voltage-gated sodium channels (Nav) are molecular targets of clinically used drugs for treatments of various diseases (epilepsy, chronic pain, cardiac arrhythmia...) and also of numerous animal and plant neurotoxins. The development of easy-to-use screening assays for the search of new ligands from chemicals libraries, animal venoms or plant extracts represents a challenge of a great interest to generate therapeutic hits. Here, we used the mammalian GH3B6 pituitary cell line, which constitutively expresses three different neuronal Nav channels isoforms (Nav1.2, Nav1.3 and Nav1.6), to identify novel compounds of pharmacological interest from a library of in-house natural alkaloids. For this screening, we developed a method based on the use of Voltage-Sensor Probes (VSPs) that we adapted to detect both activators and blockers of Nav channels. Among the 62 alkaloids tested, 11 appeared as potent Nav channels inhibitors. Five other compounds were characterized as specific gating modifiers. While most of these alkaloids are already described in the literature, their ability to modulate Nav channels was unknown. In conclusion, we report here the suitability of this novel VSPs-based screening method i) to challenge the discovery and ii) to assess the activity of novel ligands on Nav channels.

\section{PERIPHERAL INTERACTIONS BETWEEN CANNABINOID AND OPIOID SYSTEMS CONTRIBUTE TO THE ANTINOCICEPTIVE EFFECT OF CROTALPHINE}

Y. Cury ${ }^{\text {a, }}$, G. Picolo ${ }^{\text {a }}$, F.C. Machado ${ }^{\text {a }}$, A.S. Heimann ${ }^{\text {b }}$, C. Remuzgo a , S.C. Sampaio a ${ }^{a}$ Instituto Butantan, 1500, Vital Brasil Av., São Paulo, SP, 05503900, Brazil; ' Proteimax Biotechnology, Cotia, 06713-330, Brazil

Crotalphine (CRP), a peptide that was first isolated from the South American rattlesnake C.d. terrificus venom, induces a potent and long-lasting anti-nociceptive effect when administered in low doses by oral, i.v. or intraplantar routes. This effect is mediated, at peripheral level, by activation of $\kappa$ - and $\delta$-opioid receptors, of the NO-cGMP pathway and opening of ATP-sensitive $\mathrm{K}^{+}$channels. In vivo and in vitro studies also showed that MAPKs are involved in the effect of this peptide, being activation of these kinases mediated by $\kappa$-opioid receptors and dependent on activation of PKC- $\zeta$. In contrast to other opioid drugs, prolonged treatment with crotalphine does not cause the development of tolerance to antinociception or delayed hyperalgesia. Although showing opioid activity, the amino acid sequence of crotalphine does not show homology to any known opioid peptide. Binding assays have demonstrated that CRP does not directly bind

\footnotetext{
* Corresponding author.
} 